Author affiliations appear at the end of this article.

Published online ahead of print at www.jco.org on April 25, 2016.

Supported by ZonMW, Deutsche Krebshilfe (Grant No. 111092), the Institute of Health Carlos III (Grants No. PI09/02221 and PI12/01635), the Red Temática de Investigación Cooperativa en Cáncer (Grants No. RD12/0036/0034 and RD12/0036/0073), and the European Cooperation in Science and Technology action (Grant No. BM1204).

H.V. and I.I. contributed equally to this work.

Authors' disclosures of potential conflicts of interest are found in the article online at www.jco.org. Author contributions are found at the end of this article.

Corresponding author: Hans Vasen, MD, $\mathrm{PhD}$, Department of Gastroenterology and Hepatology, Leiden University Medical Center, Albinusdreef 2, 2333 ZA Leiden, the Netherlands; e-mail:

hfavasen@stoet.nl.

(c) 2016 by American Society of Clinical Oncology

0732-183X/16/3499-1/\$20.00

DOI: $10.1200 / J C 0.2015 .64 .0730$

\title{
Benefit of Surveillance for Pancreatic Cancer in High-Risk Individuals: Outcome of Long-Term Prospective Follow-Up Studies From Three European Expert Centers
}

Hans Vasen, Isaura Ibrahim, Carmen Guillen Ponce, Emily P. Slater, Elvira Matthäi, Alfredo Carrato, Julie Earl, Kristin Robbers, Anneke M. van Mil, Thomas Potjer, Bert A. Bonsing, Wouter H. de Vos tot Nederveen Cappel, Wilma Bergman, Martin Wasser, Hans Morreau, Günter Klöppel, Christoph Schicker, Martin Steinkamp, Jens Figiel, Irene Esposito, Evelina Mocci, Enrique Vazquez-Sequeiros, Alfonso Sanjuanbenito, Maria Muñoz-Beltran, José Montans, Peter Langer, Volker Fendrich, and Detlef K. Bartsch

See accompanying editorial doi:10.1200/JCO.2016.66.5265

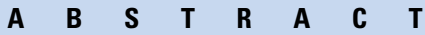

\section{Purpose}

Pancreatic ductal adenocarcinoma (PDAC) has a poor prognosis. Hereditary factors play a role in the development of PDAC in 3\% to 5\% of all patients. Surveillance of high-risk groups, may facilitate detection of PDAC at an early stage. The aim of this study was to assess whether surveillance aids detection of early-stage PDAC or precursor lesions (PRLs) and improves the prognosis.

\section{Patients and Methods}

Screening outcomes were collected from three European centers that conduct prospective screening in high-risk groups including families with clustering of PDAC (familial pancreatic cancer [FPC]) or families with a gene defect that predisposes to PDAC. The surveillance program consisted of annual magnetic resonance imaging, magnetic resonance cholangiopancreatography, and/or endoscopic ultrasound.

\section{Results}

Four hundred eleven asymptomatic individuals participated in the surveillance programs, including 178 CDKN2A mutation carriers, 214 individuals with FPC, and 19 BRCA1/2 or PALB2 mutation carriers. PDAC was detected in $13(7.3 \%)$ of 178 CDKN2A mutation carriers. The resection rate was $75 \%$, and the 5 -year survival rate was $24 \%$. Two CDKN2A mutation carriers (1\%) underwent surgical resection for low-risk PRL. Two individuals $(0.9 \%)$ in the FPC cohort had a pancreatic tumor, including one advanced PDAC and one early grade 2 neuroendocrine tumor. Thirteen individuals with FPC (6.1\%) underwent surgical resection for a suspected PRL, but only four (1.9\%) had high-risk lesions (ie, high-grade intraductal papillary mucinous neoplasms or grade 3 pancreatic intraepithelial neoplasms). One BRCA2 mutation carrier was found to have PDAC, and another BRCA2 mutation carrier and a PALB2 mutation carrier underwent surgery and were found to have low-risk PRL. No serious complications occurred as consequence of the program.

\section{Conclusion}

Surveillance of CDNK2A mutation carriers is relatively successful, detecting most PDACs at a resectable stage. The benefit of surveillance in families with FPC is less evident.

\section{J Clin Oncol 34. (C) 2016 by American Society of Clinical Oncology}

\section{INTRODUCTION}

Pancreatic ductal adenocarcinoma (PDAC) has a poor prognosis, with a 5 -year survival rate of only $5 \% .{ }^{1}$ Despite progress in our understanding of PDAC development and improvements in surgical techniques, the survival rate has not substantially changed since the introduction of pancreaticoduodenectomy 80 years ago. Currently, surgical resection is the only potentially curative treatment for PDAC, but in approximately $80 \%$ of symptomatic patients, the tumor is already unresectable at the time of diagnosis. Improvement in the resectability of tumors requires detection of PDAC at an earlier stage. Selective screening of individuals at high risk for PDAC might be one way to reach this goal.

Hereditary factors play a role in the development of PDAC in 3\% to $5 \%$ of all patients, ${ }^{2}$ and 
individuals at increased risk of developing PDAC can be subdivided into those with an underlying gene defect such as CDKN2A, $B R C A 1 / 2, P A L B 2$, and STK11 mutations and those individuals with a significant family history of PDAC (familial pancreatic cancer [FPC].$^{3}$ The risk of PDAC varies from $5 \%$ to $36 \%$ depending on the underlying gene defect. ${ }^{4-7}$ Disease risk in FPC depends on the number of relatives with PDAC and varies from $8 \%$ (two relatives) to $30 \%$ (three relatives). ${ }^{3}$

Surveillance of these high-risk groups may lead to early detection of PDAC or detection of precursor lesions (PRLs), allowing curative surgical treatment. However, before undertaking surveillance on a global scale, we need to first establish whether the surveillance program meets the screening criteria set out by Wilson and Jungner. ${ }^{8}$ Surveillance of individuals at high risk for PDAC complies with most of these requirements. The target group (ie, individuals with a substantial risk of PDAC $[>10 \%]$ ) is well defined. Although the natural history of the disease is not completely known, studies have reported that patients with FPC as well as carriers of a CDKN2A mutation frequently develop PRLs including pancreatic intraepithelial neoplasms (PanINs) and intraductal papillary mucinous neoplasms (IPMNs). ${ }^{9}$

Surveillance tools (magnetic resonance imaging [MRI], magnetic resonance cholangiopancreatography $[\mathrm{MRCP}]$, and endoscopic ultrasound [EUS]) that are able to detect small PRLs are available. ${ }^{10-14}$ The surveillance program does not seem to be burdensome for the patients. ${ }^{15}$ However, it is not yet known whether the surveillance program meets the most important criteria, which are the early detection of cancer or PRLs and an improved prognosis. Previous studies reported data on the yields of surveillance but did not address the benefit of programs in terms of survival. ${ }^{10-14,16-21}$

In the current study, we evaluated the long-term outcome of prospective surveillance of a large series of CDKN2A/p16-Leiden mutation carriers, BRCA1/2 and PALB2 mutation carriers, and individuals at risk (IARs) for FPC conducted at three expert centers in Marburg, Germany; Leiden, the Netherlands; and Madrid, Spain. The aim of the study was to assess whether surveillance leads to detection of early-stage PDAC or to the detection of relevant PRLs and to evaluate whether the program leads to improvements in prognosis.

\section{PATIENTS AND METHODS}

\section{Study Design}

The current study was made possible through the collaboration of three tertiary referral centers: the Department of Surgery at Philipps University in Marburg, the Department of Medical Oncology at Ramon y Cajal University Hospital in Madrid, and the Department of Gastroenterology at Leiden University Medical Center in Leiden. The study design was a retrospective evaluation of an ongoing prospective follow-up study. The three centers have conducted screening programs for IARs for PDAC over the past 4 to 15 years. The number of high-risk individuals and the type of hereditary PDAC or type of familial PDAC (ie, families with two first-degree relatives with PDAC [FPC2] or families with at least three firstdegree relatives with PDAC [FPC3]) in the three centers are listed in Table 1. Only asymptomatic individuals were offered surveillance.

A detailed description of patient selection has been published previously. ${ }^{22,23}$ At Leiden University Medical Center, individuals with the Dutch founder mutation, a 19-base pair deletion of exon 2 of the CDKN2A gene p16-Leiden, were referred to the Department of Gastroenterology by a clinical geneticist. Only patients with a proven CDKN2A mutation or individuals diagnosed with a personal history of melanoma and a known mutation in the family were selected for the program. At Philipps University, a national registry for families with familial PDAC (the FaPaCa Registry) was established in $1999 .{ }^{24}$ Individuals from families with two or three first-degree relatives with PDAC were offered surveillance. Members of FPC families were also recruited through physician referral, the counseling office of the Deutsche Krebshilfe, or the FaPaCa Web site. In Madrid, patients were selected through a case-control study of patients with newly diagnosed pancreatic cancer and through 17 familial cancer units set up in Spain. ${ }^{25}$

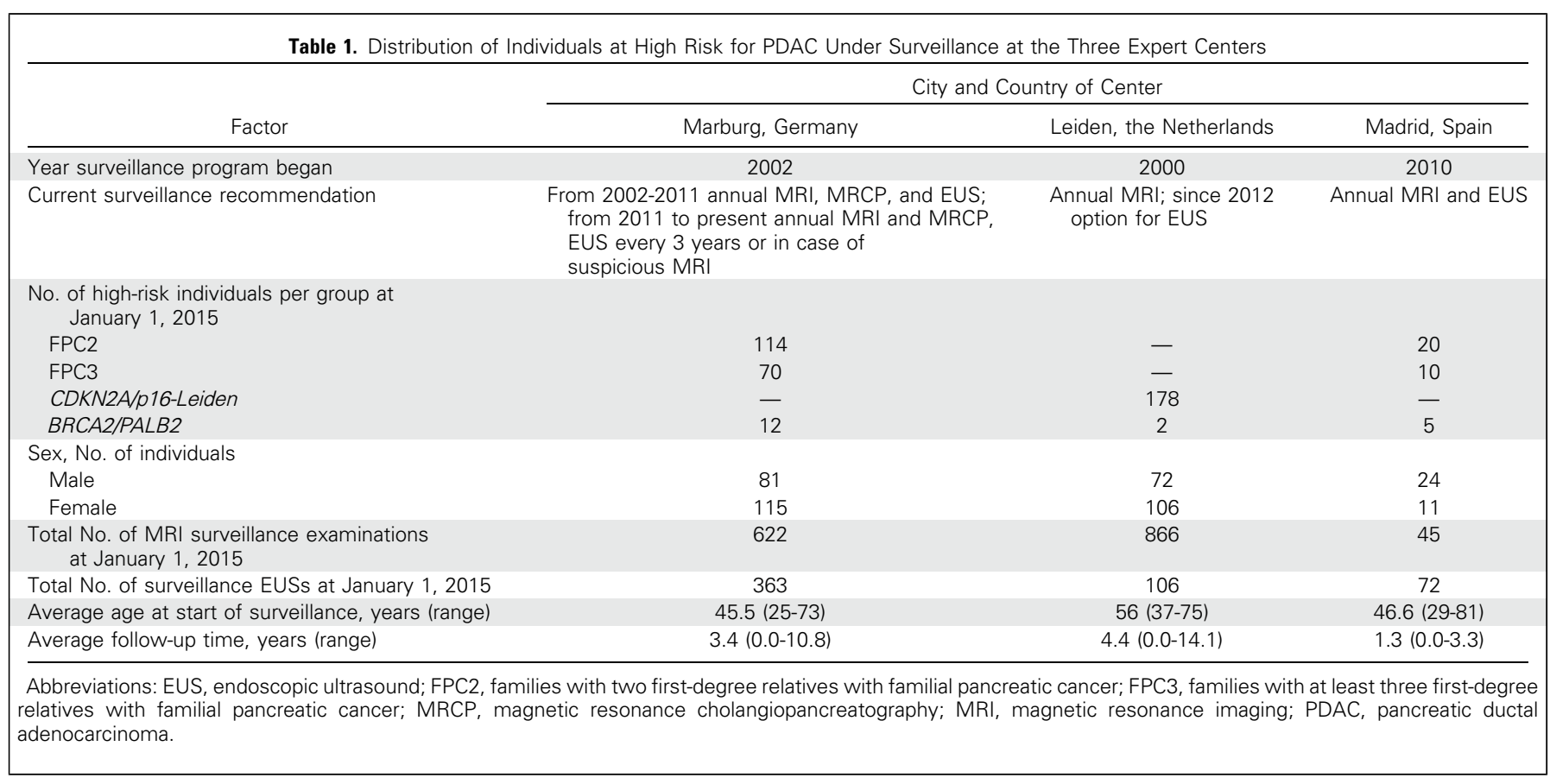


In Leiden, surveillance started at the age of 45 years. In Marburg and Madrid, surveillance started at age 40 or 10 years earlier than the youngest age at diagnosis in the family.

The current study is an update of the outcome of surveillance that was published previously. ${ }^{2,23}$ All participants were fully informed of the advantages and disadvantages of the program. The study was approved by the ethics committees of the respective centers.

\section{Surveillance Protocol}

The CDKN2A/p16-Leiden mutation carriers in Leiden were invited for an annual MRI/MRCP. Beginning in 2012, EUS was also offered as an option in addition to annual MRI. In the event of a small lesion, MRI was repeated 3 to 6 months later. In cases where there was serious suspicion of PDAC, additional EUS and CT scanning was performed. The surveillance program in Marburg included annual screening by MRI with MRCP and EUS between 2002 and 2010. Since 2011, follow-up imaging consisted of annual MRI with MRCP and EUS every third year or in case of suspicious MRI findings. If there was suspicion for a significant abnormality, IARs underwent repeated imaging after 4 weeks supplemented with EUS-guided fine-needle aspiration (FNA) in some individuals. The surveillance program in Madrid included annual EUS and MRI. All patients with confirmed suspicious lesions at the three centers were discussed within a multidisciplinary team, and a decision was made regarding the need of surgery. The criteria that were generally used to propose surgery were as follows: multiple cystic lesions greater than $10 \mathrm{~mm}$, in particular, cystic lesions that showed significant growth or a solid component; solitary cystic lesions greater than $30 \mathrm{~mm}$; solid lesions greater than $5 \mathrm{~mm}$ confirmed by MRI, EUS, and CT scanning, especially, those that increase in size; a dilated main pancreatic duct $(>10 \mathrm{~mm})$; and positive results of a biopsy.

The surveillance protocols used at the three centers are listed in Table 1. The data collected include number of IARs with a PRL or PDAC, age at diagnosis and surgery, site of the PRL and cancer, type of surgery, complications, histologic type of PRL, stage of PDAC, and survival rate of patients with PDAC. The observation time was from the start of the screening programs until January 1, 2015. In the evaluation of the surveillance program, we consider the program a success if a high-risk PRL (PanIN grade 3 lesions or IPMN with high-grade dysplasia) was detected and treated or an early PDAC (T1N0M0 with negative resection margins) was resected.

\section{Statistical Analysis}

Age-specific cumulative incidence of PDAC in the CDKN2A/p16Leiden mutation carriers and the PDAC survival were calculated using Kaplan-Meier survival analysis. Analysis of the data was conducted using the SPSS version 23.0 (SPSS, Chicago, IL).

\section{RESULTS}

\section{CDKN2A/p16-Leiden Mutation Carriers}

Patient characteristics. One hundred seventy-eight CDKN2A mutation carriers comprising 177 p16-Leiden mutation carriers and one carrier of a CDKN2A (c.67G $>$ C, G23R) mutation were included in the study; 106 of these patients $(59.6 \%)$ were women, and $72(40.4 \%)$ were men. The mean age at the start of the program was 56 years (range, 37 to 75 years), and the mean follow-up time was 53 months (range, 0 to 169 months). Seventeen patients (9.6\%) were lost to follow-up. A total of 866 MRIs and 106 EUSs were performed.

Surveillance outcomes: Pancreatic cancer. PDAC was detected in $13(7.3 \%)$ of the 178 mutation carriers, including eight women and five men. The mean age at diagnosis was 58 years (range, 39 to 74 years). The cumulative incidence of PDAC was $14 \%$ by the age of 70 years (Fig 1). Five tumors were diagnosed at first screening, and eight were detected during follow-up. Four tumors were located in the head of the pancreas, five in the tail, three in the body, and one in the transition area from head to body (Table 2). Nine patients underwent surgery, including three who underwent a distal pancreatectomy, two a Whipple procedure, one a subtotal pancreatectomy, one a resection of the body and a distal pancreatectomy, and two a distal pancreatectomy including splenectomy. In five (56\%) of the nine patients, the lymph nodes were free of tumor, and in seven (78\%) of nine patients, the resection margin was free of tumor. Of the four patients who did not undergo surgery, two patients had distant metastasis of PDAC, and a third

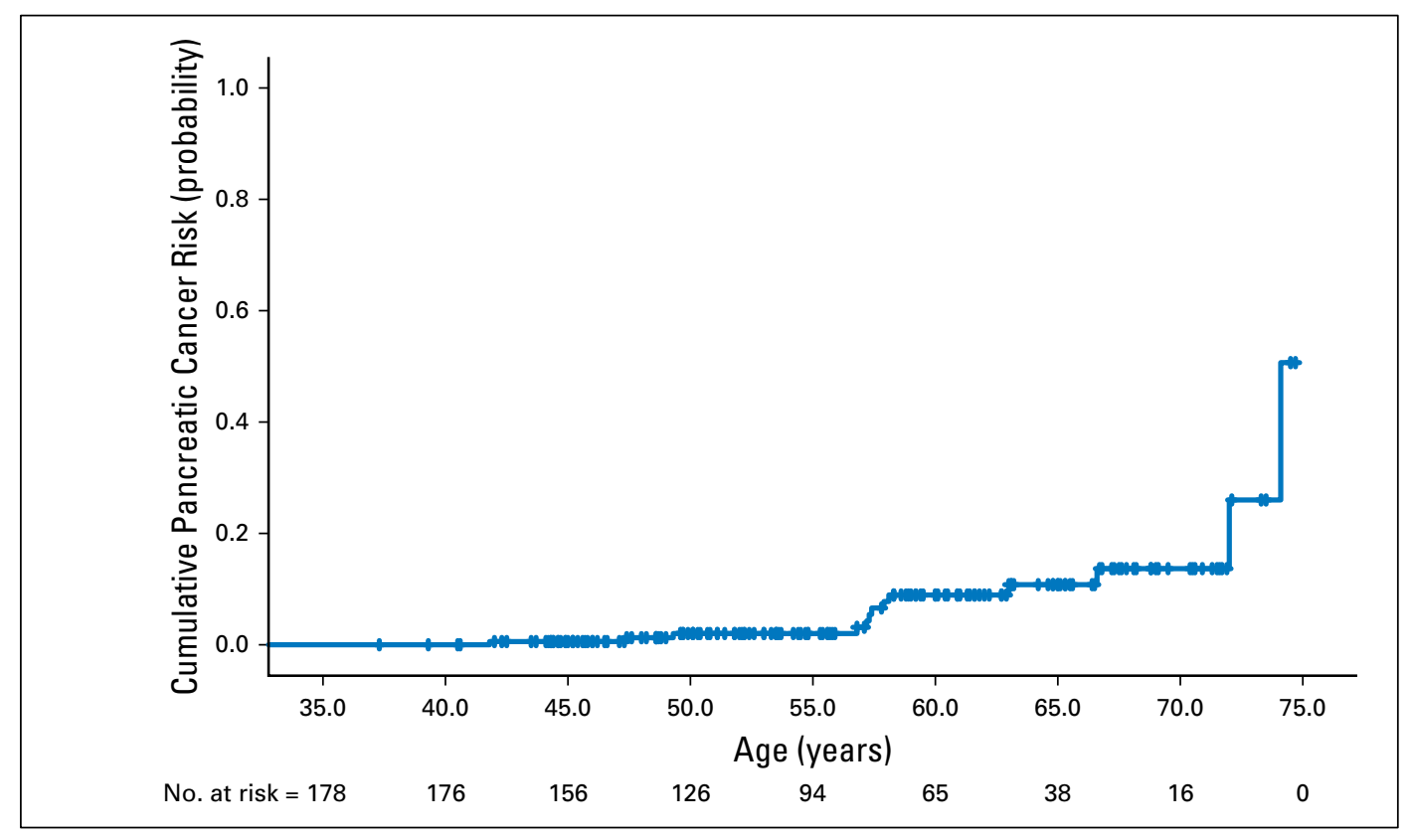

Fig 1. Cumulative incidence of pancreatic ductal adenocarcinoma for CDKN2A/p16 mutation carriers. 


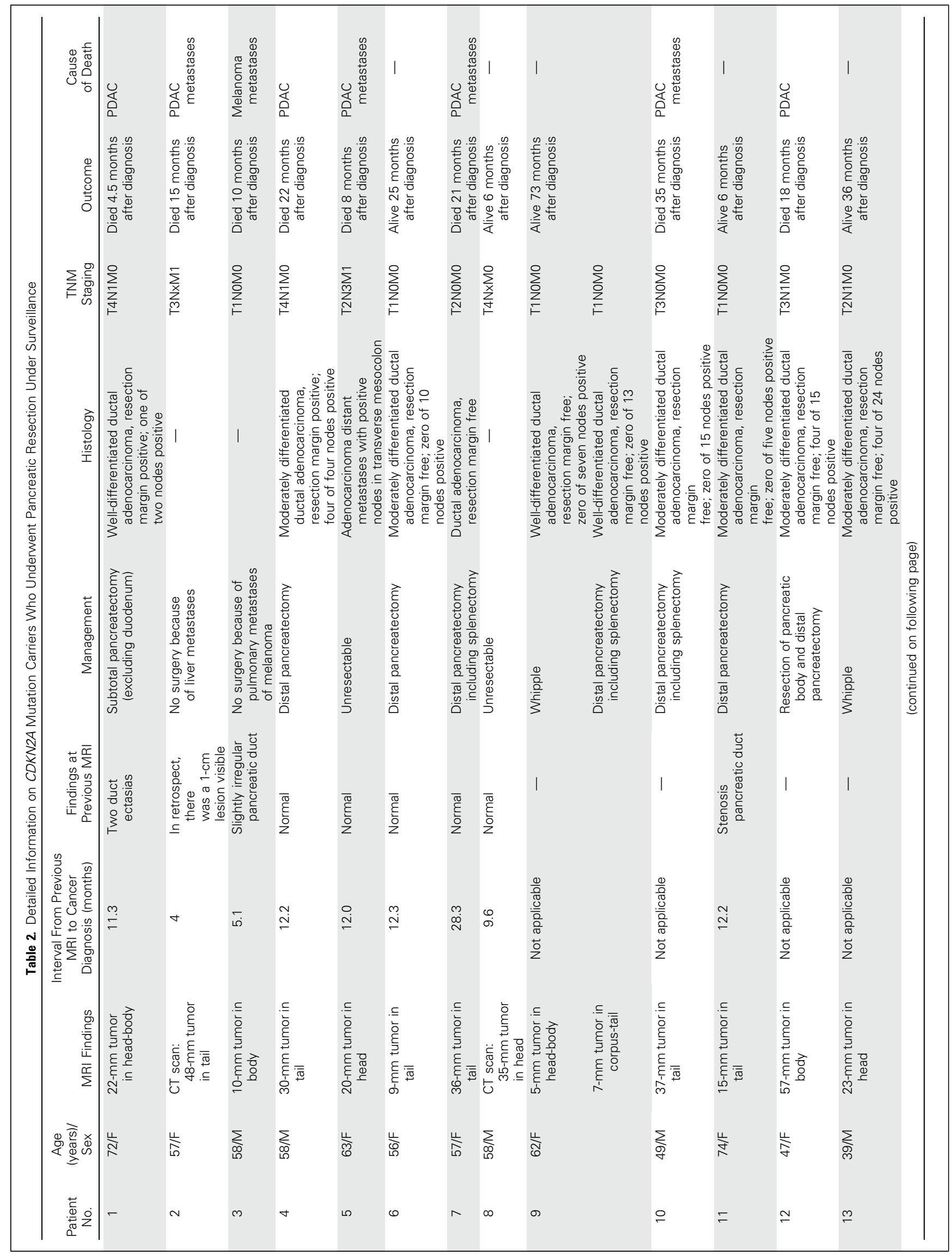

4 () 2016 by American Society of Clinical Oncology 


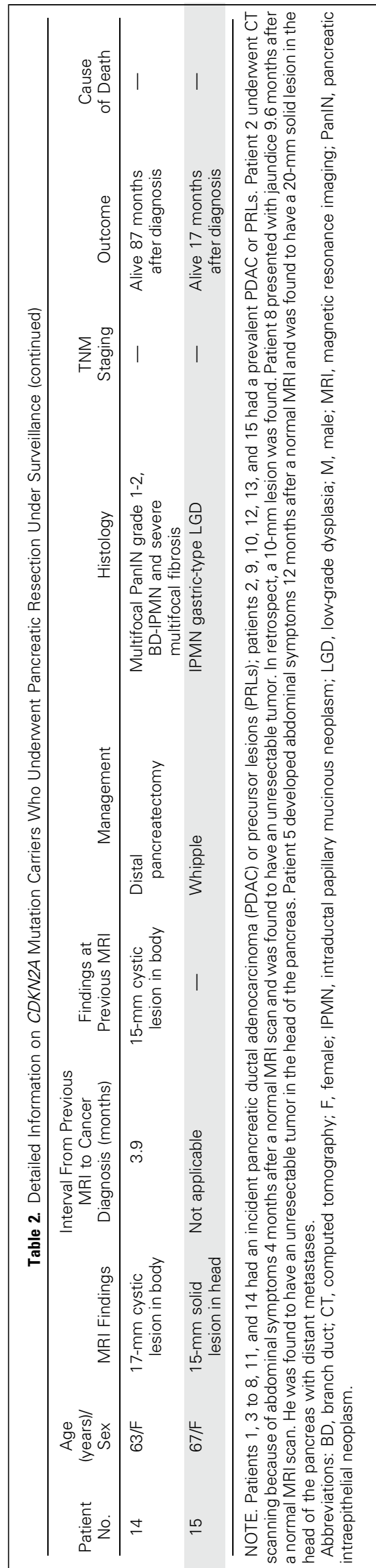


patient had extensive local disease. The fourth patient was found to have a small resectable pancreatic lesion but did not undergo surgical resection as a result of extensive pulmonary metastasis of a melanoma. The MRI images suggested that the pancreatic mass was a PDAC and not a melanoma metastasis. The overall resection rate was $75 \%$.

One patient developed a second PDAC 54 months after a Whipple procedure of the primary tumor and underwent a distal pancreatectomy. ${ }^{26}$ Eight of the 13 patients died; seven patients died as a result of PDAC, and one patient died as a result of melanoma metastases. The overall 5-year survival rate was $24 \%$ (Fig 2). In terms of screening efficiency, 14 patients needed to be screened to detect one PDAC, and a total of 67 MRIs were needed to detect one PDAC.

Surveillance outcomes: PRLs. In 26 (14.6\%) of 178 CDKN2A/ p16-Leiden mutation carriers, a cystic lesion was found. Two individuals (1\%), both women, underwent surgery (Table 2).

In the first patient, the initial MRI/MRCP (2001) at the age of 63 years showed multiple ductectasia in side branches in the body of the pancreas with a diameter of $15 \mathrm{~mm}$. In 2008, there was slight growth of the lesion, and an extended distal pancreatectomy was subsequently performed. Histologic examination revealed multifocal PanIN grade 1 to 2 lesions with branch duct (BD) IPMN and severe multifocal lobulocentric fibrosis. The patient is currently doing well 7.2 years later.

The second patient underwent a Whipple procedure at the age of 67 years as a result of a $15-\mathrm{mm}$ solid lesion in the uncinate process detected at first MRI. Histologic examination revealed an IPMN gastric type with low-grade dysplasia. Seventeen months after surgery, the patient has slightly increased serum values of alkaline phosphatase and $\gamma$-glutamyltransferase but is asymptomatic and in a good health.

\section{IARs for FPC}

Patient characteristics. This patient group included 214 individuals, including 99 men and 115 women. One hundred thirty-four individuals were from FPC2 families, and 80 were from FPC3 families.

Average age at start of the surveillance program was 48.2 years (range, 27 to 81 years), and the mean follow-up time was 2.8 years (range, 0.0 to 10.8 years). A total of 618 MRIs and 402 EUSs were performed as part of the follow-up program.

Surveillance outcomes: Pancreatic cancer. In the FPC group, the program detected a lesion suspected for PDAC in three female patients (1.4\%). The first patient was a 53-year-old member of an FPC3 family. She missed two MRI screening visits and was diagnosed 26 months after the last normal screening visit with a $30-\mathrm{mm}$ solid tumor in the head of the pancreas. The patient underwent a total pancreatectomy. Histologic examination showed a ductal adenocarcinoma $\mathrm{pT} 3 \mathrm{~N} 1$ (nine positive lymph nodes out of 22) M0 with tumor-free resection margins. The patient died 38 months after surgery as a result of metastatic disease.

The second patient was a 47-year-old member of an FPC3 family. At the first EUS, a 7-mm cystic lesion was visible in the body of the pancreas, which was subsequently confirmed by CT scanning. Two years later, the lesion was $10 \mathrm{~mm}$. An EUS-guided FNA biopsy revealed malignant cells. The patient subsequently underwent a distal pancreatectomy and splenectomy. The surgical specimen showed a serous cystadenoma with atypical changes but no cancer. This patient is alive 1 year after surgery.

The third individual was a member of an FPC2 family. EUS at the age of 48 revealed a 5 - $\mathrm{mm}$ solid lesion in the tail of the pancreas. FNA biopsy showed a grade 2 neuroendocrine tumor. After distal pancreatectomy, the surgical specimen showed a T1 grade 2 neuroendocrine tumor, with tumor-free lymph nodes and resection margins. The patient is alive 2 years after surgery.

Surveillance outcomes: PRLs. Cystic lesions were detected in $112(52 \%)$ of 214 IARs. A total of 13 patients (6.1\%) underwent surgical resection because of suspicious lesions. The average age at surgery was 56 years (range, 42 to 69 years). Six IARs belonged to FPC2 families, and seven IARs belonged to FPC3 families.

Suspicious lesions were diagnosed at the first examination in five IARs (38.5\%) and during follow-up in eight IARs $(61.5 \%)$. The

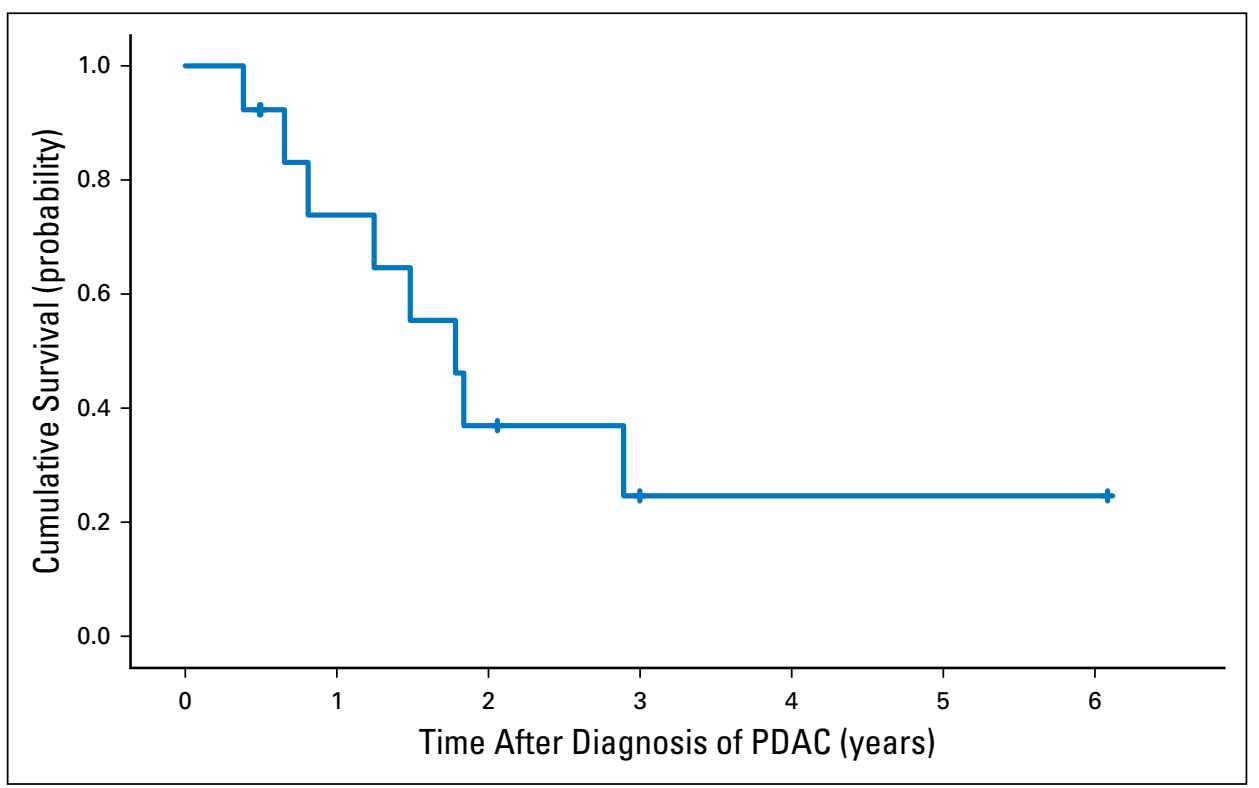

Fig 2. Overall survival of CDKN2A/p16 mutation carriers with pancreatic ductal adenocarcinoma (PDAC) detected during surveillance. 
Table 3. Detailed Information on Individuals at Risk for FPC Who Underwent Pancreatic Resection

\begin{tabular}{|c|c|c|c|c|c|c|c|c|}
\hline $\begin{array}{l}\text { Patient } \\
\text { No.* }\end{array}$ & $\begin{array}{l}\text { Age (years)/ } \\
\text { Sex }\end{array}$ & Disorder & MRI Findings & $\begin{array}{l}\text { Incident or } \\
\text { Prevalent }\end{array}$ & Management & Histology & Outcome & $\begin{array}{l}\text { Cause of } \\
\text { Death }\end{array}$ \\
\hline 1 & $52 / \mathrm{M}$ & FPC2 & $\begin{array}{l}\text { Dilated main } \\
\text { pancreatic duct } \\
\text { with stenosis, } \\
\text { head }\end{array}$ & Prevalent & Whipple & $\begin{array}{l}\text { Main duct IPMN } \\
\text { HGD }\end{array}$ & $\begin{array}{l}\text { Alive } 30 \text { months after } \\
\text { surgery }\end{array}$ & - \\
\hline 2 & $58 / F$ & FPC2 & $\begin{array}{l}\text { Multiple }(2-8 \mathrm{~mm}) \\
\text { cystic lesions, } \\
\text { body and tail }\end{array}$ & Incident & $\begin{array}{l}\text { Total } \\
\text { pancreatectomy }\end{array}$ & $\begin{array}{l}\text { Multifocal PanIN } \\
\text { grade 2, BD- } \\
\text { IPMN LGD, AFL }\end{array}$ & $\begin{array}{l}\text { Died } 22 \text { months after } \\
\text { surgery }\end{array}$ & Klatskin tumor \\
\hline 3 & $52 / F$ & FPC3 & $\begin{array}{l}\text { Two ductectesia } \\
\text { (5 and } 7 \mathrm{~mm} \text { ) }\end{array}$ & Incident & $\begin{array}{l}\text { Total } \\
\text { pancreatectomy }\end{array}$ & $\begin{array}{l}\text { Multifocal PanIN } \\
\text { grade 2, PanIN } \\
\text { grade 3, AFL }\end{array}$ & $\begin{array}{l}\text { Alive } 55 \text { months after } \\
\text { surgery }\end{array}$ & - \\
\hline 4 & $64 / F$ & FPC2 & $\begin{array}{c}\text { Multiple }(2-13 \mathrm{~mm}) \\
\text { cystic lesions, } \\
\text { body and tail }\end{array}$ & Incident & $\begin{array}{l}\text { Total } \\
\text { pancreatectomy }\end{array}$ & $\begin{array}{l}\text { Multifocal PanIN } \\
\text { grade 2, PanIN } \\
\text { grade 3, BD- } \\
\text { IPMN LGD, AFL }\end{array}$ & $\begin{array}{l}\text { Alive } 49 \text { months after } \\
\text { surgery }\end{array}$ & - \\
\hline 5 & $69 / F$ & FPC3 & $\begin{array}{l}\text { Multiple }(3-10 \mathrm{~mm}) \\
\text { ductectesia, } \\
\text { body and tail }\end{array}$ & Prevalent & $\begin{array}{l}\text { Total } \\
\text { pancreatectomy }\end{array}$ & $\begin{array}{l}\text { Multifocal PanIN } \\
\text { grade 2, PanIN } \\
\text { grade } 3\end{array}$ & $\begin{array}{l}\text { Alive } 16 \text { months after } \\
\text { surgery }\end{array}$ & - \\
\hline 6 & $47 / M$ & FPC3 & $\begin{array}{l}\text { 10-mm cystic } \\
\text { lesion, head }\end{array}$ & Incident & Whipple & $\begin{array}{l}\text { Multifocal PanIN } \\
\text { grade 2, BD- } \\
\text { IPMN LGD }\end{array}$ & $\begin{array}{l}\text { Alive } 29 \text { months after } \\
\text { surgery }\end{array}$ & - \\
\hline 7 & $54 / F$ & FPC3 & $\begin{array}{l}\text { Multiple cystic } \\
\text { lesions ( } 3-10 \\
\text { mm), body and } \\
\text { tail }\end{array}$ & Incident & $\begin{array}{l}\text { Distal } \\
\text { pancreatectomy }\end{array}$ & $\begin{array}{l}\text { Multifocal PanIN } \\
\text { grade 2, BD- } \\
\text { IPMN LGD, AFL }\end{array}$ & $\begin{array}{l}\text { Alive } 3 \text { months after } \\
\text { surgery }\end{array}$ & - \\
\hline 8 & $53 / F$ & FPC3 & $\begin{array}{l}\text { 8-mm hypointense } \\
\text { lesion, tail }\end{array}$ & Incident & $\begin{array}{l}\text { Distal } \\
\quad \text { pancreatectomy }\end{array}$ & $\begin{array}{l}\text { PanIN grade 2, BD- } \\
\text { IPMN LGD }\end{array}$ & $\begin{array}{l}\text { Alive } 88 \text { months after } \\
\text { surgery }\end{array}$ & - \\
\hline 9 & $55 / \mathrm{M}$ & FPC3 & $\begin{array}{l}\text { 6-mm } \\
\text { hypointensive } \\
\text { lesion, tail }\end{array}$ & Prevalent & $\begin{array}{l}\text { Distal } \\
\text { pancreatectomy }\end{array}$ & $\begin{array}{l}\text { Lobular fibrosis } \\
\text { with PanIN grade } \\
1 \text { lesion }\end{array}$ & $\begin{array}{l}\text { Alive } 94 \text { months after } \\
\text { surgery }\end{array}$ & - \\
\hline 10 & $60 / \mathrm{M}$ & FPC2 & $\begin{array}{l}\text { 7-mm hypointense } \\
\text { lesion, tail }\end{array}$ & Prevalent & $\begin{array}{l}\text { Distal } \\
\text { pancreatectomy }\end{array}$ & $\begin{array}{l}\text { Focal fibrosis with } \\
\text { PanIN grade } 1 \\
\text { lesion }\end{array}$ & $\begin{array}{l}\text { Alive } 120 \text { months after } \\
\text { surgery }\end{array}$ & - \\
\hline 11 & $61 / F$ & FPC3 & $\begin{array}{l}\text { Cystic lesions (14 } \\
\text { and } 22 \mathrm{~mm} \text { ), } \\
\text { head and tail }\end{array}$ & Prevalent & $\begin{array}{l}\text { Distal } \\
\text { pancreatectomy }\end{array}$ & $\begin{array}{l}\text { Serous } \\
\quad \text { cystadenoma }\end{array}$ & $\begin{array}{l}\text { Alive } 132 \text { months after } \\
\text { surgery }\end{array}$ & - \\
\hline 12 & $42 / F$ & FPC2 & $\begin{array}{l}\text { Lobulated 32-mm } \\
\text { macrocystic } \\
\text { lesion, tail }\end{array}$ & Incident & $\begin{array}{l}\text { Distal } \\
\text { pancreatectomy }\end{array}$ & $\begin{array}{l}\text { Serous } \\
\quad \text { cystadenoma }\end{array}$ & $\begin{array}{l}\text { Alive } 98 \text { months after } \\
\text { surgery }\end{array}$ & - \\
\hline 13 & $61 / F$ & FPC2 & $\begin{array}{l}\text { Normal (EUS 6-mm } \\
\text { hypoechogenic } \\
\text { lesion, body) }\end{array}$ & Incident & $\begin{array}{l}\text { Distal } \\
\text { pancreatectomy }\end{array}$ & $\begin{array}{l}\text { Serous } \\
\text { cystadenoma }\end{array}$ & $\begin{array}{l}\text { Alive } 86 \text { months after } \\
\text { surgery }\end{array}$ & - \\
\hline 14 & $53 / F$ & FPC3 & $\begin{array}{l}\text { 24-mm solid lesion, } \\
\text { head; small } \\
\text { cystic lesions, } \\
\text { body and tail }\end{array}$ & Incident & $\begin{array}{l}\text { Total } \\
\text { pancreatectomy }\end{array}$ & $\begin{array}{l}\text { Ductal } \\
\text { adenocarcinoma; } \\
9 \text { of } 22 \text { nodes } \\
\text { positive, } \\
\text { pT3N1M0 }\end{array}$ & $\begin{array}{l}\text { Died } 38 \text { months after } \\
\quad \text { surgery }\end{array}$ & $\begin{array}{l}\text { PDAC } \\
\text { metastases }\end{array}$ \\
\hline 15 & $47 / F$ & FPC3 & $\begin{array}{l}\text { 10-mm cystic } \\
\text { lesion }\end{array}$ & Prevalent & $\begin{array}{l}\text { Distal } \\
\text { pancreatectomy } \\
\text { including } \\
\text { splenectomy }\end{array}$ & $\begin{array}{l}\text { FNA biopsy: } \\
\text { malignant cells; } \\
\text { surgical } \\
\text { specimen: } \\
\text { serous } \\
\text { cystadenoma, no } \\
\text { (residual) cancer }\end{array}$ & $\begin{array}{l}\text { Alive } 13 \text { months after } \\
\text { surgery }\end{array}$ & - \\
\hline 16 & $48 / F$ & FPC2 & $\begin{array}{l}\text { Normal (EUS 5-mm } \\
\text { solid lesion in } \\
\text { body) }\end{array}$ & Prevalent & $\begin{array}{l}\text { Distal } \\
\text { pancreatectomy }\end{array}$ & $\begin{array}{l}\text { T1 grade } 2 \\
\text { neuroendocrine } \\
\text { tumor, resection } \\
\text { margins free; no } \\
\text { positive nodes }\end{array}$ & $\begin{array}{l}\text { Alive } 28 \text { months after } \\
\text { surgery }\end{array}$ & - \\
\hline
\end{tabular}

Abbreviations: AFL, atypical flat lesion; BD, branch duct; EUS, endoscopic ultrasound; F, female; FNA, fine-needle aspiration; FPC, familial pancreatic cancer; FPC2, families with two first-degree relatives with familial pancreatic cancer; FPC3, families with at least three first-degree relatives with familial pancreatic cancer; HGD, highgrade dysplasia; IPMN, intraductal papillary mucinous neoplasm; LGD, low-grade dysplasia; M, male; MRI, magnetic resonance imaging; PanIN, pancreatic intraepithelial neoplasm; PDAC, pancreatic ductal adenocarcinoma.

*Patient 15 underwent surgery in Madrid, Spain; all other patients underwent surgery in Marburg, Germany.

lesions were mainly located in the pancreatic body and tail of IARs $(\mathrm{n}=11)$; two IARs had suspicious lesions in the pancreatic head (Table 3).

Seven patients underwent a distal pancreatectomy, five patients a total pancreatectomy, and one patient a Whipple procedure.
One additional patient underwent surgical exploration because of a suspicious lesion, but no abnormalities were found.

High-risk PRLs, including grade 3 PanIN $(n=3)$ and IPMN gastric type with high-grade dysplasia $(n=1)$, were detected on histopathologic analysis in four (1.9\% of all screened cases) 


\begin{tabular}{|c|c|c|c|c|c|c|c|c|}
\hline$\underset{*}{\text { Patient No. }}$ & $\begin{array}{c}\text { Age (years)/ } \\
\text { Sex }\end{array}$ & Disorder & MRI Findings & $\begin{array}{c}\text { Incident or } \\
\text { Prevalent }\end{array}$ & Management & Histology & Outcome & Cause of Death \\
\hline 1 & $68 / F$ & BRCA2 & $\begin{array}{l}\text { Solid lesion (17 } \times \\
12 \mathrm{~mm} \text { ) in the tail }\end{array}$ & Incident & $\begin{array}{l}\text { Distal } \\
\text { pancreatectomy }\end{array}$ & $\begin{array}{l}\text { Ductal } \\
\text { adenocarcinoma; } \\
\text { resection } \\
\text { margins free; } \\
\text { zero of } 16 \text { lymph } \\
\text { nodes positive }\end{array}$ & $\begin{array}{l}\text { Died } 17 \text { months } \\
\text { after surgery }\end{array}$ & $\begin{array}{l}\text { PDAC } \\
\text { metastases }\end{array}$ \\
\hline 2 & $71 / F$ & PALB2 & $\begin{array}{l}\text { Multiple cystic } \\
\text { lesions ( } 3-7 \mathrm{~mm}) \\
\text { in head }\end{array}$ & Prevalent & Whipple & $\begin{array}{l}\text { Multifocal PanIN } \\
\text { grade 2, BD- } \\
\text { IPMN LGD }\end{array}$ & $\begin{array}{l}\text { Alive } 21 \text { months } \\
\text { after surgery }\end{array}$ & - \\
\hline 3 & $67 / F$ & $B R C A 2$ & $\begin{array}{l}\text { Multiple cystic } \\
\text { lesions ( } 3-8 \mathrm{~mm} \text { ) } \\
\text { in body and tail }\end{array}$ & Prevalent & $\begin{array}{l}\text { Total } \\
\text { pancreatectomy }\end{array}$ & $\begin{array}{c}\text { Multifocal PanIN } \\
\text { grade } 2, \mathrm{AFL}\end{array}$ & $\begin{array}{l}\text { Alive } 10 \text { months } \\
\text { after surgery }\end{array}$ & - \\
\hline
\end{tabular}

of 13 IARs. Another four IARs revealed multifocal grade 2 PanIN lesions in combination with BD-IPMNs of the gastric type and/or atypical flat lesions, ${ }^{27}$ whereas three IARs showed serous cystadenomas and two IARs showed focal fibrosis with grade 1B PanIN lesions. Thus, five IARs (2.3\%) were overtreated.

Four of 13 IARs developed postoperative complications, including three who developed a pancreatic fistula and one who had had a postoperative bleeding after Whipple resection at the pancreaticogastrostomy, which could be managed endoscopically. Twelve IARs are alive without evidence of relevant pancreatic lesions after a median follow-up of 52 months. One female patient developed an adenocarcinoma of the biliary tract 22 months after surgery and died as a result of liver failure.

\section{BRCA1/2 or PALB2 Mutation Carriers}

Patient characteristics. Nineteen individuals carried a BRCA1/ 2 or PALB2 mutation, including seven men and 12 women. One individual had a $B R C A 1$ mutation, 12 individuals had a $B R C A 2$ mutation, and six individuals had a PALB2 mutation. Average age at start of the program was 52.6 years (range, 25 to 70 years), and the average follow-up time was 32.7 months (range, 1 to 119 months).

Surveillance outcomes. In this cohort, only one individual (3.8\%), a woman with a BRCA2 mutation, developed PDAC (Table 4). The lesion was detected at age 68 years. The previous MRI 1 year before revealed a small side BD-IPMN at the transition from head to body. The patient underwent a distal pancreatectomy that showed a 19-mm lesion in the tail; resection margins were free, and all lymph nodes were negative (zero of 16 nodes). Seventeen months after surgery, the patient died as a result of liver metastasis.

Two individuals underwent surgery for cystic lesions. The first patient was a 71-year-old woman with a PALB2 mutation. She underwent a Whipple procedure after finding a $12-\mathrm{mm}$ lesion on the first MRI and EUS. Histology showed multifocal grade 2 PanIN lesions and BD-IPMNs with low-grade dysplasia. The patient is in good condition 21 months after surgery. The second patient was a 67-year-old woman with a BRCA2 mutation. Multiple cystic lesions ( 3 to $8 \mathrm{~mm}$ ) were detected on the first MRI. She demanded to undergo a total pancreatectomy. Histology showed multifocal grade 2 PanIN and atypical flat lesions. The patient is in good health 10 months after surgery.

\section{DISCUSSION}

The current study demonstrated that the resection rate of screendetected PDAC in CDKN2A/p16-Leiden mutation carriers (75\%) was much higher than reported for sporadic PDAC patients $(15 \%$ to $20 \%$ ) and for historical controls of CDKN2A/p16-Leiden mutation carriers with symptomatic PDAC (15\%). ${ }^{23}$ The 5 -year survival rate was substantially higher $(24 \%)$ than the survival rate reported for patients with symptomatic sporadic PDAC ( $4 \%$ to $7 \%)^{28}$

PRLs were much more frequent in patients with FPC than in CDKN2A/p16-Leiden mutation carriers. Surgical resection was performed in 13 patients $(6.1 \%)$ with FPC. According to the definition of high-risk lesions proposed by the expert group, ${ }^{29}$ only four lesions (1.9\% of all screened patients) were high-risk lesions (grade 3 PanIN or high-grade gastric-type IPMN). However, another four IARs showed multifocal grade 2 PanIN lesions in combination with low-grade gastric-type BD-IPMNs and/or atypical flat lesions. Thus, the question arises of whether multifocal grade 2 PanIN lesions and low-grade IPMNs are also relevant PRLs for PDAC in the setting of FPC. In a large autopsy study, grade 2 PanIN lesions (previously referred to as atypical hyperplasia or low-grade dysplasia) were reported in $29 \%$ of patients with PDAC and only $0.7 \%$ of individuals without PDAC, suggesting that grade 2 PanIN lesions are also strongly associated with PDAC development. ${ }^{30}$ Although the time interval and rate at which grade 2 PanIN lesions progress to invasive cancer is unknown, one can hypothesize that multifocal grade 2 PanIN lesions and atypical flat lesions are biologically relevant in the setting of FPC. ${ }^{27}$

The strengths of the current study were the design as a prospective long-term follow-up study and the inclusion of a large series of high-risk individuals. In addition, family history in 
patients with FPC was verified by medical and pathology reports in greater than $95 \%$ of all patients. Furthermore, all participants in the Leiden series were found to have either a CDKN2A mutation or a personal history of melanoma and a close relative with a CDKN2A mutation. A weakness of the study was the lack of a control group.

One of the most important criteria defined by Wilson and Jungner $^{8}$ was that surveillance should improve prognosis. Without a control group, it is difficult to determine with certainty the effects of the surveillance program on PDAC outcome. However, in view of the high resection rate and the better survival compared with the survival rates reported for patients with sporadic PDAC, surveillance of $C D K N 2 A / p 16$-Leiden carriers complies with this requirement.

However, whether surveillance of FPC families meets this criterion is still questionable. The yield of PDAC is low $(0.9 \%)$, and most screen-detected PDACs reported in the literature were advanced cancers. ${ }^{3}$ Likewise, the yield in terms of detection of relevant PRLs (grade 3 PanIN and high-grade IPMN) was low (1.9\%). However, if surgical removal of multifocal grade 2 PanIN and multifocal BD-IPMNs is regarded as beneficial, the diagnostic yield increases to $3.7 \%$ (eight of 214 patients), and surveillance of FPC might also be considered effective.

In summary, surveillance of $C D N K 2 A$ mutation carriers was relatively successful, detecting most PDACs at a resectable stage. The value of surveillance of FPC is still not clear, and the main effect seems to be prevention of PDAC by removal of PRLs.

\section{AUTHORS' DISCLOSURES OF POTENTIAL CONFLICTS} OF INTEREST

Disclosures provided by the authors are available with this article at www.jco.org.

\section{AUTHOR CONTRIBUTIONS}

Conception and design: Hans Vasen, Isaura Ibrahim, Carmen Guillen Ponce, Emily P. Slater, Alfredo Carrato, Anneke M. van Mil, Bert A. Bonsing, Wouter H. de Vos tot Nederveen Cappel, Wilma Bergman, Martin Wasser, Hans Morreau, Christoph Schicker, Enrique Vazquez-Sequeiros, José Montans, Detlef K. Bartsch

Provision of study materials or patients: Peter Langer, Volker Fendrich Collection and assembly of data: Hans Vasen, Isaura Ibrahim, Carmen Guillen Ponce, Emily P. Slater, Elvira Matthäi, Alfredo Carrato, Julie Earl, Kristin Robbers, Thomas Potjer, Günter Klöppel, Martin Steinkamp, Jens Figiel, Irene Esposito, Evelina Mocci, Alfonso Sanjuanbenito, Maria Muñoz-Beltran, Volker Fendrich, Detlef K. Bartsch

Data analysis and interpretation: Hans Vasen, Isaura Ibrahim, Emily P. Slater, Julie Earl, Irene Esposito, José Montans, Peter Langer, Detlef K. Bartsch

Manuscript writing: All authors

Final approval of manuscript: All authors

\section{REFERENCES}

1. Siegel RL, Miller $K D$, Jemal $A$ : Cancer statistics, 2015. CA Cancer J Clin 65:5-29, 2015

2. Shi $C$, Hruban RH, Klein AP: Familial pancreatic cancer. Arch Pathol Lab Med 133:365-374, 2009

3. Bartsch DK, Gress TM, Langer P: Familial pancreatic cancer: Current knowledge. Nat Rev Gastroenterol Hepatol 9:445-453, 2012

4. de Snoo FA, Bishop DT, Bergman W, et al: Increased risk of cancer other than melanoma in CDKN2A founder mutation (p16-Leiden)-positive melanoma families. Clin Cancer Res 14:7151-7157, 2008

5. van Lier MG, Wagner A, Mathus-Vliegen EM, et al: High cancer risk in Peutz-Jeghers syndrome: A systematic review and surveillance recommendations. Am J Gastroenterol 105:1258-1264, 2010

6. Vasen HF, Gruis NA, Frants RR, et al: Risk of developing pancreatic cancer in families with familial atypical multiple mole melanoma associated with a specific 19 deletion of p16 (p16-Leiden). Int J Cancer 87:809-811, 2000

7. van Asperen CJ, Brohet RM, Meijers-Heijboer EJ, et al: Cancer risks in BRCA2 families: Estimates for sites other than breast and ovary. J Med Genet 42:711-719, 2005

8. Wilson JMG, Jungner G: Principles and Practice of Screening for Disease. Geneva, Switzerland, World Health Organization, 1968

9. Potjer TP, Schot I, Langer $P$, et al: Variation in precursor lesions of pancreatic cancer among highrisk groups. Clin Cancer Res 19:442-449, 2013
10. Al-Sukhni W, Borgida $A$, Rothenmund $H$, et al: Screening for pancreatic cancer in a high-risk cohort: An eight-year experience. J Gastrointest Surg 16: 771-783, 2012

11. Canto MI, Goggins M, Yeo CJ, et al: Screening for pancreatic neoplasia in high-risk individuals: An EUS-based approach. Clin Gastroenterol Hepatol 2: 606-621, 2004

12. Canto Ml, Goggins $M$, Hruban $R H$, et al: Screening for early pancreatic neoplasia in high-risk individuals: A prospective controlled study. Clin Gastroenterol Hepatol 4:766-781, 2006

13. Harinck F, Konings IC, Kluijt I, et al: A multicentre comparative prospective blinded analysis of EUS and MRI for screening of pancreatic cancer in high-risk individuals. Gut pii:gutjnl-2014-308008, 2015

14. Langer $P$, Kann $P H$, Fendrich $V$, et al: Five years of prospective screening of high-risk individuals from families with familial pancreatic cancer. Gut 58: 1410-1418, 2009

15. Harinck F, Nagtegaal $T$, Kluijt I, et al: Feasibility of a pancreatic cancer surveillance program from a psychological point of view. Genet Med 13: 1015-1024, 2011

16. Brentnall TA: Pancreatic cancer surveillance: Learning as we go. Am J Gastroenterol 106:955-956, 2011

17. Canto $\mathrm{MI}$, Hruban $\mathrm{RH}$, Fishman EK, et al: Frequent detection of pancreatic lesions in asymptomatic high-risk individuals. Gastroenterology 142 : 796-804, 2012

18. Del Chiaro $M$, Verbeke CS, Kartalis $N$, et al: Short-term results of a magnetic resonance imagingbased Swedish screening program for individuals at risk for pancreatic cancer. JAMA Surg 150:512-518, 2015

19. Kimmey MB, Bronner MP, Byrd DR, et al: Screening and surveillance for hereditary pancreatic cancer. Gastrointest Endosc 56:S82-S86, 2002 (suppl 4)

20. Poley JW, Kluijt I, Gouma DJ, et al: The yield of first-time endoscopic ultrasonography in screening individuals at a high risk of developing pancreatic cancer. Am J Gastroenterol 104:2175-2181, 2009

21. Verna EC, Hwang C, Stevens PD, et al: Pancreatic cancer screening in a prospective cohort of high-risk patients: A comprehensive strategy of imaging and genetics. Clin Cancer Res 16:5028-5037, 2010

22. Schneider $R$, Slater EP, Sina M, et al: German national case collection for familial pancreatic cancer ( $\mathrm{FaPaCa})$ : Ten years experience. Fam Cancer 10: 323-330, 2011

23. Vasen HF, Wasser M, van Mil A, et al: Magnetic resonance imaging surveillance detects early-stage pancreatic cancer in carriers of a p16-Leiden mutation. Gastroenterology 140:850-856, 2011

24. Bartsch DK, Sina-Frey $M$, Ziegler $A$, et al: Update of familial pancreatic cancer in Germany. Pancreatology 1:510-516, 2001

25. Mocci E, Guillen-Ponce C, Earl J, et al: PanGen-Fam: Spanish registry of hereditary pancreatic cancer. Eur J Cancer 51:1911-1917, 2015

26. Potjer TP, Bartsch DK, Slater EP, et al: Limited resection of pancreatic cancer in high-risk patients can result in a second primary. Gut 64:1342-1344, 2015 
27. Aichler $M$, Seiler $C$, Tost $M$, et al: Origin of pancreatic ductal adenocarcinoma from atypical flat lesions: A comparative study in transgenic mice and human tissues. J Pathol 226:723-734, 2012
28. Integraal Kankercentrum Nederland: Dutch Cancer Registry. www.cijfersoverkanker.nl

29. Canto $\mathrm{Ml}$, Harinck $\mathrm{F}$, Hruban $\mathrm{RH}$, et al: International Cancer of the Pancreas Screening (CAPS) Consortium summit on the management of patients with increased risk for familial pancreatic cancer. Gut 62:339-347, 2013

30. Kozuka S, Sassa R, Taki T, et al: Relation of pancreatic duct hyperplasia to carcinoma. Cancer 43 1418-1428, 1979

\section{Affiliations}

Hans Vasen, Isaura Ibrahim, Kristin Robbers, Anneke M. van Mil, Thomas Potjer, Bert A. Bonsing, Wilma Bergman, Martin Wasser, and Hans Morreau, Leiden University Medical Center, Leiden; Wouter H. de Vos tot Nederveen Cappel, Isala Clinics, Zwolle, the Netherlands; Carmen Guillen Ponce, Alfredo Carrato, Julie Earl, Evelina Mocci, Enrique Vazquez-Sequeiros, Alfonso Sanjuanbenito, Maria Muñoz-Beltran, and José Montans, Ramón y Cajal University Hospital, Ramón y Cajal Health Research Institute, Madrid, Spain; Emily P. Slater, Elvira Matthäi, Volker Fendrich, and Detlef K. Bartsch, University Hospital Marburg; Christoph Schicker, Martin Steinkamp, and Jens Figiel, Philipps University Marburg, Marburg; Günter Klöppel, Consultation Centre for Pancreatic and Endocrine Tumors, Technical University Munich; Peter Langer, Klinikum Hanau, Hanau, Germany; and Irene Esposito, Innsbruck University Hospital, Innsbruck, Austria. 


\section{AUTHORS' DISCLOSURES OF POTENTIAL CONFLICTS OF INTEREST}

Benefit of Surveillance for Pancreatic Cancer in High-Risk Individuals: Outcome of Long-Term Prospective Follow-Up Studies From Three European Expert Centers

The following represents disclosure information provided by authors of this manuscript. All relationships are considered compensated. Relationships are self-held unless noted. I = Immediate Family Member, Inst = My Institution. Relationships may not relate to the subject matter of this manuscript. For more information about ASCO's conflict of interest policy, please refer to www.asco.org/rwc or jco.ascopubs.org/site/ifc.

\section{Hans Vasen}

No relationship to disclose

\section{Isaura Ibrahim}

No relationship to disclose

\section{Carmen Guillen Ponce}

Consulting or Advisory Role: Bayer Hispania, Celgene, Merck Serono, Amgen, Sanofi

Speakers' Bureau: Celgene, Merck Serono, Roche Pharma

Travel, Accommodations, Expenses: Roche Pharma, Sanofi

\section{Emily P. Slater}

No relationship to disclose

Elvira Matthäi

No relationship to disclose

\section{Alfredo Carrato}

Consulting or Advisory Role: Roche, Bayer, Merck, Sanofi, Celgene, Amgen

Speakers' Bureau: Bayer, Merck, Celgene, Amgen

Travel, Accommodations, Expenses: Roche, Merck

\section{Julie Earl}

No relationship to disclose

\section{Kristin Robbers}

No relationship to disclose

Anneke M. van Mil

No relationship to disclose

\section{Thomas Potjer}

No relationship to disclose

Bert A. Bonsing

No relationship to disclose

Wouter H. de Vos tot Nederveen Cappel

No relationship to disclose

Wilma Bergman

No relationship to disclose

\section{Martin Wasser}

No relationship to disclose

\section{Hans Morreau}

No relationship to disclose

\section{Günter Klöppel}

No relationship to disclose

Christoph Schicker

No relationship to disclose

\section{Martin Steinkamp}

No relationship to disclose

Jens Figiel

No relationship to disclose

Irene Esposito

Research Funding: Novartis (Inst)

Travel, Accommodations, Expenses: Roche Austria

Evelina Mocci

No relationship to disclose

Enrique Vazquez-Sequeiros

No relationship to disclose

Alfonso Sanjuanbenito

Speakers' Bureau: Celgene

Maria Muñoz-Beltran

No relationship to disclose

José Montans

Honoraria: Cellgene Espana S.L.

Peter Langer

No relationship to disclose

Volker Fendrich

No relationship to disclose

Detlef K. Bartsch

No relationship to disclose 


\section{Acknowledgment}

We thank F.J. Hes, R.A. Veenendaal, A. Inderson, N.A. Gruis, J. Dengler, T.M. Gress, P.H. Kann, A. Mahnken, and A. Ramaswamy for contributing to this article. 